\title{
Sequential changes in hepatic mRNA abundance and serum concentration of serum amyloid $A$ in cattle with acute inflammation caused by endotoxin
}

\author{
Marina OTSUKA ${ }^{1)}$, Yasunobu NISHI ${ }^{1)}$, Kenji TSUKANO ${ }^{1)}$, Masakazu TSUCHIYA ${ }^{2)}$, \\ Jeffrey LAKRITZ3) and Kazuyuki SUZUKI ${ }^{1) *}$ \\ ${ }^{1)}$ School of Veterinary Medicine, Rakuno Gakuen University, 582 Bunkyodai-Midorimachi, Ebetsu, \\ Hokkaido 069-8501, Japan \\ ${ }^{2)}$ Microbial Solutions, Charles River, 1023 Wappoo Road, Suite 43B, Charleston, SC 29407, USA \\ ${ }^{3)}$ College of Veterinary Medical Science, Ohio State University, 1900 Coffey Road, Columbus, OH 43210, USA
}

\section{J. Vet. Med. Sci.}

82(7): 1006-1011, 2020

doi: 10.1292/jvms.19-0629

Received: 21 November 2019 Accepted: 20 May 2020

Advanced Epub: 2 June 2020

\begin{abstract}
The objective of the present study was to elucidate sequential changes in mRNA abundance of serum amyloid A (SAA) isotypes in endotoxin (ETX) challenge model cattle. Ten healthy cattle were separated to 2 groups: control and ETX groups. Cattle in the ETX group were challenged by $2.5 \mu \mathrm{g} / \mathrm{kg}$ of 0111:B4 lipopolysaccharide in $4 \mathrm{~m} /$ of autologous serum. Blood samples were withdrawn at pre, 0.5, 1, 2, 4, 8, 12, 24, 48, 72 and $96 \mathrm{hr}$ after ETX challenge. Plasma ETX activity, serum SAA concentrations, mRNA abundance of interleukin (IL)-6, SAA2 and SAA4 in the liver and polymorphonuclear leukocytes were measured. The plasma ETX activity in the ETX group increased at $0.5 \mathrm{hr}$ after the ETX challenge. The serum SAA value remained higher between 12 and $72 \mathrm{hr}$ after the ETX challenge than that of the control group. Hepatic IL-6 mRNA abundance in the ETX group increased at $2 \mathrm{hr}$ after the ETX challenge. Hepatic SAA2 and SAA4 mRNA abundance significantly increased from $4 \mathrm{hr}$ after administration, and remained significantly higher than those pre-values up to 12 and $24 \mathrm{hr}$, respectively. The abundance ratio of hepatic SAA2 was much higher than that of SAA4. The major isotype was SAA2 in liver tissue, and it is indicating systemic inflammation in cattle.
\end{abstract}

KEY WORDS: acute phase protein, bovine, endotoxin, inflammation, serum amyloid $A$

Because inflammatory diseases in cattle are major causes of economic loss [11,20], diagnostic markers for cattle to estimate the severity of inflammation and prognosis are important. It is well known that the concentrations of serum amyloid A (SAA), one of acute phase proteins (APPs), in serum increase in the early stages of inflammation in cattle [5, 7]. SAA is mainly synthesized in the liver and released into the systemic circulation in response to inflammation [8, 9, 24]. Many studies reported that SAA is useful to evaluate inflammation in cattle $[1,2,4,7,10,13,14,21,28]$.

The role of SAA is to inhibit lymphocyte and endothelial cell proliferation, platelet aggregation, and phagocytosis. It also stimulates the migration of monocytes and neutrophils, and the synthesis of prostaglandins and metalloproteinases [23]. The SAA mRNA transcription is carried out mainly in hepatocytes under the influence of IL-1 $\alpha$, IL-6 and tumor necrosis factor- $\alpha$ (TNF- $\alpha$ ) [3]. The SAA is the generic name of a family of proteins that share high levels of sequence homology but are encoded by different genes: $S A A 1, S A A 2, S A A 3$ and $S A A 4$ [26]. Four SAA isoforms (SAA1, SAA2, SAA3 and SAA4) translated from each gene are included in the SAA family. However, it is known that there are species differences in the expression of SAA isoforms. Bovine SAA proteins, like humans, are SAA 1 to 4, and SAA 1 and 2 are classic proteins for acute phase response (APR) [5]. The SAA3 isoform is known as mammary-associated SAA in cattle and ewes [5, 16-19, 23], and is detected in high concentrations in colostrum [22] and mastitic milk [15]. SAA4 is a constitutively expressed protein, and apolipoprotein of the high-density lipoprotein complex [27]. The physiological function of SAA4 is unknown, and its serum concentration has no association with those of other major apolipoproteins.

In several studies aimed to evaluate time courses of SAA and other APPs, serum SAA increased in systemic inflammatory model cattle that endotoxin (ETX) challenged $[4,12,28]$. However, to the best of our knowledge, no studies have investigated sequential changes in mRNA expression of SAA isoform genes in ETX challenge model cattle. The objective of the present study was to elucidate sequential changes in mRNA abundance of SAA isotypes in ETX challenge model cattle. 


\section{MATERIALS AND METHODS}

This animal study was performed in accordance with the Guide for the Care and Use of Laboratory Animals of the School of Veterinary Medicine at Rakuno Gakuen University (Approval\#: VC16C1). Ten Holstein-Friesian cattle, aged six months old and weighing $170.6 \pm 36.5 \mathrm{~kg}$, were enrolled. All cattle were clinically normal before the experiment based on vital signs, attrition, food and water intakes, and urine and feces production. Clinical signs, such as moist rales on auscultation, moist cough, jugular vein congestion, exophthalmos, salivation and arrhythmia, were not observed before the experiment. A complete and balanced growth diet consisting of pelleted concentrate rations and mixed grass hay was provided, and cattle have unlimited access to fresh water.

All cattle were fit with an indwelling jugular catheter immediately before the ETX was infused, and received $2.5 \mu \mathrm{g} / \mathrm{kg}$ bolus doses of O111:B4 lipopolysaccharide (L4391, Sigma-Aldrich, St. Louis, MO, USA) intravenously in $4 \mathrm{ml}$ of autologous serum via the catheter. It is designed after a method used by Hinds et al. [12]. Blood samples $(10 \mathrm{~m} l)$ were withdrawn from the contralateral jugular vein before (pre), and 0.5, 1, 2, 4, 8, 12, 24, 48, 72 and $96 \mathrm{hr}$ after the ETX challenge, and stored in heparine-2K-coated tubes (for plasma ETX assay), serum-separating tubes (for serum SAA assay) and EDTA-coated tubes (for real-time PCR). Serum and plasma were harvested after centrifugation at 3,000 rpm at room temperature for 15 min and stored at $-80^{\circ} \mathrm{C}$ until analysis.

Hepatic biopsies were carried out on the 10th and 11th intercostal spaces at pre, and $0.5,1,2,4,8,12$ and $24 \mathrm{hr}$ after challenge using a 14-G biopsy needle (Quick-cut C2, Hakko, Tokyo, Japan) with a 13-mm-notch under local anesthesia by $2.5 \mathrm{~m} l$ of $2 \%$ lidocaine hydrochloride (Xylocaine injection 2\%, Astrazeneca, Osaka, Japan). To prevent hemorrhage on liver, the hepatic biopsy was performed under ultrasound (LogiqBook, GE Healthcare, Wauwatosa, WI, USA)-guide. Hepatic specimens obtained by hepatic biopsy were immediately soaked in RNA stabilization reagent (RNAlater RNA Stabilization Reagent, Qiagen, Hilden, Germany), and then homogenized using a rotor-stator homogenizer with a disposable head (bio-masher II, Wako, Tokyo, Japan) within 24 hr after collection. In addition, although SAA is mainly expressed in liver and epithelial cells [5, 24], the amount of mRNA present in polymorphonuclear leukocytes (PMN) was also measured as reference to confirm that SAA is not expressed in PMN. PMN was separated from EDTA treated blood by centrifugation after hemolysis of red blood cells using hemolytic reagent (Red Blood Cell Lysis Buffer, Roche Diagnostics, Basel, Switzerland), according to the instructions.

Plasma ETX activities were measured by commercial limulus amebocyte lysate (LAL)-kinetic turbidimetric assays (KTA). Immediately prior to testing, plasma samples were diluted 20-fold in ETX-free water (Otsuka distilled water, Otsuka Pharmaceutical Co., Ltd., Tokyo, Japan). These specimens were vortexed for $10 \mathrm{sec}$, and then heated for $10 \mathrm{~min}$ at $80^{\circ} \mathrm{C}$ in order to inactivate interfering substances such as protease inhibitors. The ETX control standard (CSE, Control Std Endotoxin, Charles River, Charlston, SC, USA), which contained $10 \mathrm{ng}$ of ETX/vial, was dissolved to $30 \mathrm{ETX}$ unit (EU)/vial by ETX-free water and used as the positive control. The LAL reagents for LAL-KTA (Endosafe ${ }^{\circledR}$ KTA2, Charles River) assay was reconstituted with ETX specific Buffer Solution (Endotoxin-Specific Buffer Solution, Charles River) to eliminate $\beta$-glucan reaction. The LAL-based assays were performed on 96-well microplates (Endosafe ${ }^{\circledR}$ 96-well, flat bottom microplate M9001, Charles River). ETX activities were measured using a microplate reader (Sunrise ${ }^{\mathrm{TM}}$, Tecan Group Ltd., Männedorf, Switzerland) and endotoxin measuring software (EndoScan-V ${ }^{\mathrm{TM}}$, Charles River). The wave length was $340 \mathrm{~nm}$.

Serum SAA concentrations were measured using an automated latex agglutination turbidimetric immunoassay (VET-SAA 'Eiken', Eiken Chemical Co., Tokyo, Japan) on an automated clinical chemical analyzer (Hitachi 7170S, Hitachi Ltd., Tokyo, Japan) [6].

Total RNA from liver tissue and PMN was isolated using an RNA isolation kit for tissue (High Pure RNA tissue kit, Roche Diagnostics, Basel, Switzerland) and blood (High Pure RNA Isolation Kit, Roche Diagnostics) according to the instructions, respectively, and stored at $-80^{\circ} \mathrm{C}$ until analysis. The measurement targets were IL- 6 which affecting SAA production, SAA2 which associated with inflammation, and SAA4 not associated with inflammation. Abundance levels of IL-6, SAA2 and SAA4 mRNA in PMN and liver tissue were measured by real-time PCR (Light-Cycler 480 system II, Roche Diagnostics). Both reverse transcription and real-time PCR were carried out in one-step methods using a commercial kit (Light-Cycler ${ }^{\circledR}$ Multiplex RNA Virus Master version 3, Roche Diagnostics, Basel, Switzerland). The real-time PCR reaction was performed in 96-well plates with a final volume of $20 \mu l$. The PCR mixture contained $5 \mu l$ of template RNA, $1 \mu l(0.5 \mu \mathrm{M})$ of each primer (forward and reverse), $0.4 \mu l$ of Universal Probe, $4 \mu l$ of RT-PCR reaction mix, $0.1 \mu l$ of RT-Enzyme solution and $8.5 \mu l$ of water. The primers and universal probes for bovine IL-6, SAA2, SAA4 and glyceraldehyde-3-phosphate dehydrogenase (GAPDH) are shown in Table 1. According to the manufacturer's instructions, the following amplification setup and cycling parameters were used: reverse transcription at $50^{\circ} \mathrm{C}$ for $10 \mathrm{~min}$, pre-incubation at $95^{\circ} \mathrm{C}$ for $30 \mathrm{sec}$, and 45 cycles of amplification at $95^{\circ} \mathrm{C}$ for $5 \mathrm{sec}$ and $60^{\circ} \mathrm{C}$ for $30 \mathrm{sec}$. The results of relative quantification of GAPDH as a reference gene were automatically provided using commercial software (E-method, Roche Diagnostics, Basel, Switzerland).

\section{Statistical analysis}

Statistical analyses were performed using a commercial software package (IBM SPSS Statistics, v.23, IBM Co., Somers, NY, USA). The data in this study are shown as the mean \pm standard deviation. A test result of ETX activity was considered valid when spike recovery and coefficient of variation met the accepted criteria; spike recovery: $50-200 \%$, coefficient of variation $<25 \%$. The lower detection limit of ETX activity was $0.077 \mathrm{EU} / \mathrm{m} l$. Therefore, plasma ETX activity below 0.077 EU/m $l$ was statistically analyzed as $0.077 \mathrm{EU} / \mathrm{m} l$.

The obtained data from each five cattle per group were averaged for each and analyzed by using repeated-measures analysis of 
Table 1. List of primers and universal probes for bovine IL-6, serum amyloid A

(SAA) 2, SAA4 and glyceraldehyde-3-phosphate dehydrogenase (GAPDH)

\begin{tabular}{llclc}
\hline \multicolumn{2}{c}{ Primer } & Length & \multicolumn{1}{c}{ Sequence $\left(5^{\prime}-3^{\prime}\right)$} & Universal probe $^{\text {a) }}$ \\
\hline IL-6 & Forward & 20 & gectgagagctattcggatg & \#45 \\
& Reverse & 20 & tgcccaggaactaccacaat & \\
\hline SAA2 & Forward & 20 & ctatgacgctgcccaagag & \#26 \\
& Reverse & 23 & cagagggtctgtgaatctctgaa & \\
\hline SAA4 & Forward & 20 & ggaactacgaggctgctcaa & \#26 \\
& Reverse & 20 & tgaaggtactccccgacatt & \\
\hline GAPDH & Forward & 20 & ggcctccaaggagtaaggtc & \#45 \\
& Reverse & 21 & aggaactcttcctctcgtgct & \\
\hline
\end{tabular}

a) Each probe is matched for the specific primer sequence designed by using Universal ProbeLibrary.

variance (ANOVA) to assess the time course of changes in each value over $24 \mathrm{hr}$ (plasma ETX activity and mRNA abundance) or $96 \mathrm{hr}$ (serum SAA concentration), respectively. If significant differences were observed, the Dunnett post-hoc test for multiple comparisons was performed to find time points showing significant difference from the pre-value. The significance level was $P<0.05$.

\section{RESULTS}

As all values were normally distributed in this study, they were expressed as the mean \pm standard deviation.

Sequential changes in plasma ETX activity in ETX-challenged cattle are shown in Fig. 1. Pre-challenge values of plasma ETX activity were lower than detection limit $(0.077 \mathrm{EU} / \mathrm{m} l)$ in both the control and ETX groups. In plasma endotoxin activity of only cattle challenged with endotoxin, interaction between groups and time was observed $(P<0.05)$. The significant increase in plasma ETX activity was observed in ETX group compared to pre-value at $0.5 \mathrm{hr}(P<0.01)$, reaching $1.032 \pm 0.310 \mathrm{EU} / \mathrm{m} l \mathrm{at} 0.5 \mathrm{hr}$ after challenge, followed by a return to pre-challenge values after $1 \mathrm{hr}$.

Sequential changes in serum SAA concentrations in ETX-challenged cattle are shown in Fig. 2. The pre-challenge values of serum SAA concentrations in the control and ETX groups were $1.94 \pm 2.40$ and $4.77 \pm 6.77 \mu \mathrm{g} / \mathrm{ml}$, respectively. In the control group, no significant change in serum SAA concentration was observed during experimental period. While, significant increases were observed in serum SAA concentrations in ETX group between 12 and $72 \mathrm{hr}$ compered to pre-value $(12$ and $72 \mathrm{hr}: P<0.05,24$ and $48 \mathrm{hr}: P<0.01)$, reaching $123.31 \pm 21.78 \mu \mathrm{g} / \mathrm{ml}$ at $24 \mathrm{hr}$ after the ETX challenge.

In both the control and ETX groups, the pre-challenge value of IL-6 mRNA abundance ratio to GAPDH in the PMN and liver were lower than 0.0007 . In the control group, no significant changes in any genes were observed in the PMN or tissues during experimental period. On the other hand, significant increases were observed in hepatic IL- 6 mRNA abundance in ETX-challenged cattle compared to pre-challenge value at $2 \mathrm{hr}$ after ETX challenged $(P<0.05)$, reaching $0.007 \pm 0.008$ (Fig. 3A).

The sequential changes in the mRNA abundance ratio of SAA2 to GAPDH in the liver are shown in Fig. 3B. The pre-challenge value of hepatic SAA 2 mRNA abundance in the control and ETX groups were $2.85 \pm 1.35$ and $2.61 \pm 3.47$, respectively. Significant increases were observed in hepatic SAA2 mRNA abundance ratio in ETX-challenged cattle between 4 and $24 \mathrm{hr}$ compered to pre-value ( 4 to $12 \mathrm{hr}: P<0.05,24 \mathrm{hr}: P<0.01$ ), reaching $20.24 \pm 2.44$ at $8 \mathrm{hr}$ after the ETX challenge. In the PMN, the significant increase was also observed in SAA2 mRNA abundance ratio in ETX-challenged cattle at 4 hr compered to pre-value $(P<0.05$, data not shown).

The sequential changes in the mRNA abundance ratio of SAA4 to GAPDH in the liver are shown in Fig. 3C. The pre-challenge value of hepatic SAA4 in the control and ETX groups were $0.19 \pm 0.11$ and $0.29 \pm 0.24$, respectively. Significant increases were observed in hepatic SAA4 mRNA abundance ratio in ETX-challenged cattle between 4 and $12 \mathrm{hr}$ compered to pre-value (4 hr: $P<0.05,8$ and $12 \mathrm{hr}: P<0.01)$. The hepatic SAA4 mRNA abundance ratio reached $1.93 \pm 0.77$ at $8 \mathrm{hr}$ after the ETX challenge. However, there were no significant differences in the mRNA abundance ratio of SAA4 in the PMN between groups (data not shown).

\section{DISCUSSION}

The objective of the present study was to clarify sequential changes in mRNA abundance of SAA isotypes in ETX challenge model cattle. The plasma ETX activity in ETX-challenged cattle was peaked at $0.5 \mathrm{hr}$ after the ETX challenge, followed by a rapid return to the pre-challenge value. Then, the hepatic IL-6 to GAPDH mRNA abundance ratio increased at 2 hr. Subsequently, the serum SAA concentration begins to increase at $12 \mathrm{hr}$ after ETX challenge and remained high until $72 \mathrm{hr}$. This rapid increase in SAA due to inflammation is supported by previous studies using infectious model cattle $[2,10,12,15]$.

IL-6 is the major inducer of the hepatic acute phase proteins, and which is secreted by neutrophils, monocytes and macrophages upon Toll-like receptor stimulation by inflammation-inducing substance, such as ETX [3, 25]. In hepatocyte, pro-inflammatory 


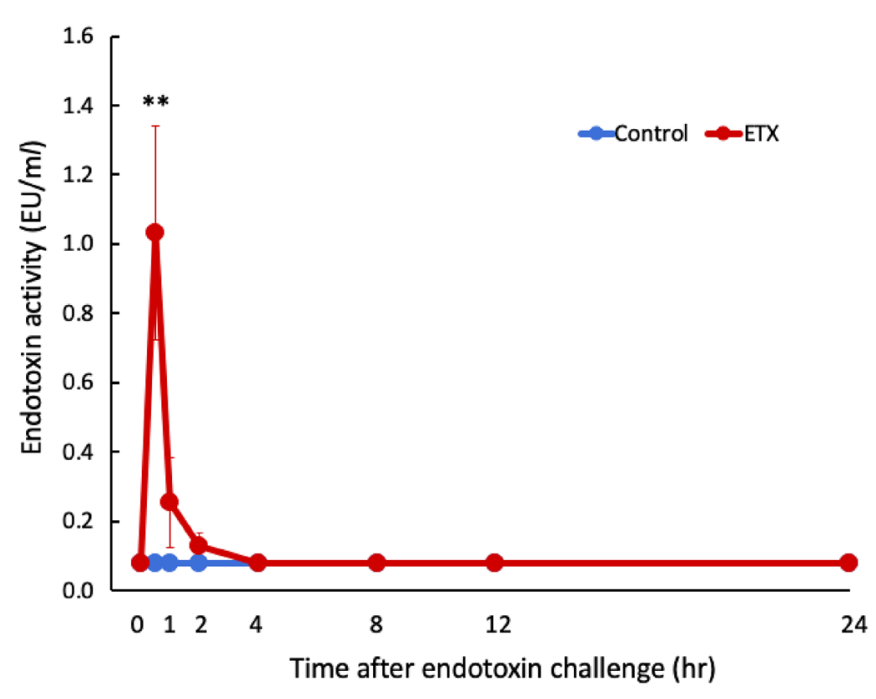

Fig. 1. Sequential changes in plasma endotoxin activity in control and endotoxin $\left(\right.$ ETX)-challenged cattle. ${ }^{* *}$ : vs. pre-value $(P<0.01)$.

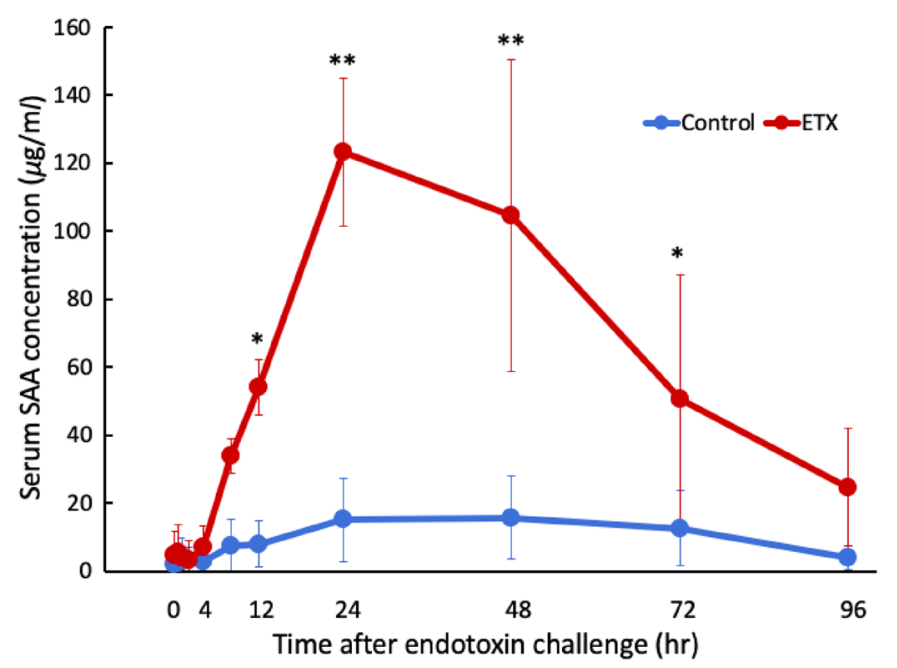

Fig. 2. Sequential changes in serum amyloid A (SAA) concentrations in control and endotoxin (ETX)-challenged cattle. *: vs. pre-value $(P<0.05), * *$ : vs. pre-value $(P<0.01)$.

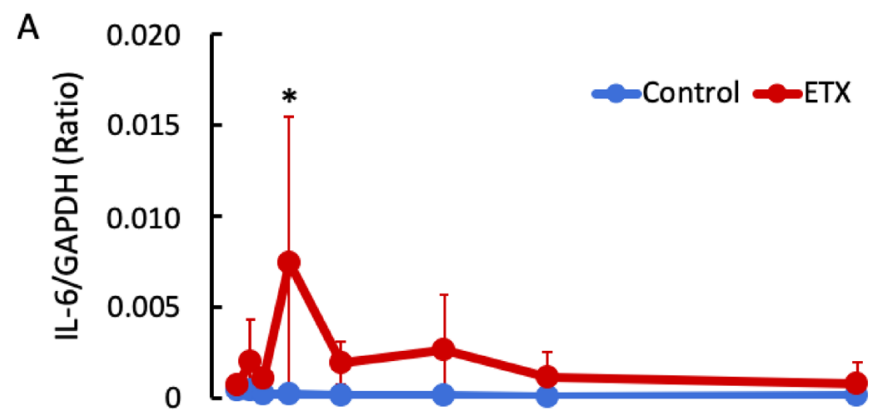

B


Fig. 3. Sequential changes in mRNA abundance ratio of IL-6 (A), serum amyloid A (SAA) 2 (B) and SAA 4 (C) in the liver. *: vs. pre-value $(P<0.05),{ }^{* *}$ : vs. pre-value $(P<0.01)$. 
cytokines such as IL- 6 and TNF- $\alpha$ activate the transcription factors STAT3 and NF-kB, and they promote the expression of many APPs including SAA $[25,27]$. The sequential changes in IL-6 and SAA observed in present study are consistent with these facts, it was considered that SAA was produced in the liver by IL-6 stimulation.

In cattle, the ETX challenge resulted in increase of SAA2 and SAA4, which was primarily in the liver. However, mRNA abundance of hepatic SAA4 was much lower than that of SAA2 in this study. This suggests that the SAA2 gene, an APP in cattle, is expressed in the liver in the acute phase of inflammation via the expression of IL-6, as described above. In addition, bovine SAA2 is the major APP isotype in the SAA family, similar to human SAA1. SAA1 and SAA2 are the genes for the classic APR serum proteins in humans and mice [24]. Considering these, bovine hepatic SAA2 is also the major APP isotype in the SAA family expressed via IL-6, similar to human SAA1. On the other hand, the ETX induced increase of bovine hepatic SAA4, despite it was not APP, might be involved read-through transcription reported in humans [24].

The significant increase of the SAA2-mRNA abundance in PMN was observed at $4 \mathrm{hr}$ after ETX challenged, however, the expression of SAA genes in PMN were minimal compared to that in liver. Although SAA gene expression was slightly observed in PMNs, the main SAA expression field was in the liver, like previous study [24] that described the SAA2 gene was expressed in the liver. In this study, it was not clear why SAA2 in PMN was upregulated by endotoxin challenge. Going forward, further studies should be required to elucidate the mechanism of extrahepatic expression of SAA2 in cattle.

In conclusion, this study demonstrated that the serum SAA concentration increases after ETX challenge, and is induced by IL- 6 and SAA2 genes expressed mainly in the liver. Of particular interest is the increase in SAA concentration was due to the SAA2 gene, which is homologous to the human inflammation related gene, not the SAA4 gene.

\section{REFERENCES}

1. Alsemgeest, S. P., Taverne, M. A., Boosman, R., van der Weyden, B. C. and Gruys, E. 1993. Peripartum acute-phase protein serum amyloid-A concentration in plasma of cows and fetuses. Am. J. Vet. Res. 54: 164-167. [Medline]

2. Alsemgeest, S. P., Kalsbeek, H. C., Wensing, T., Koeman, J. P., van Ederen, A. M. and Gruys, E. 1994. Concentrations of serum amyloid-A (SAA) and haptoglobin (HP) as parameters of inflammatory diseases in cattle. Vet. Q. 16: 21-23. [Medline] [CrossRef]

3. Berg, L. C., Thomsen, P. D., Andersen, P. H., Jensen, H. E. and Jacobsen, S. 2011. Serum amyloid A is expressed in histologically normal tissues from horses and cattle. Vet. Immunol. Immunopathol. 144: 155-159. [Medline] [CrossRef]

4. Boosman, R., Niewold, T. A., Mutsaers, C. W. and Gruys, E. 1989. Serum amyloid A concentrations in cows given endotoxin as an acute-phase stimulant. Am. J. Vet. Res. 50: 1690-1694. [Medline]

5. Ceciliani, F., Ceron, J. J., Eckersall, P. D. and Sauerwein, H. 2012. Acute phase proteins in ruminants. J. Proteomics 75: 4207-4231. [Medline] [CrossRef]

6. Christensen, M., Jacobsen, S., Ichiyanagi, T. and Kjelgaard-Hansen, M. 2012. Evaluation of an automated assay based on monoclonal anti-human serum amyloid A (SAA) antibodies for measurement of canine, feline, and equine SAA. Vet. J. 194: 332-337. [Medline] [CrossRef]

7. Eckersall, P. D. and Bell, R. 2010. Acute phase proteins: Biomarkers of infection and inflammation in veterinary medicine. Vet. J. 185: $23-27$. [Medline] [CrossRef]

8. Gabay, C. and Kushner, I. 1999. Acute-phase proteins and other systemic responses to inflammation. N. Engl. J. Med. 340: 448-454. [Medline] [CrossRef]

9. Gruys, E., Toussaint, M. J., Niewold, T. A. and Koopmans, S. J. 2005. Acute phase reaction and acute phase proteins. J. Zhejiang Univ. Sci. B 6: 1045-1056. [Medline] [CrossRef]

10. Heegaard, P. M., Godson, D. L., Toussaint, M. J., Tjørnehøj, K., Larsen, L. E., Viuff, B. and Rønsholt, L. 2000. The acute phase response of haptoglobin and serum amyloid A (SAA) in cattle undergoing experimental infection with bovine respiratory syncytial virus. Vet. Immunol. Immunopathol. 77: 151-159. [Medline] [CrossRef]

11. Hilton, W. M. 2014. BRD in 2014: where have we been, where are we now, and where do we want to go? Anim. Health Res. Rev. 15: $120-122$. [Medline] [CrossRef]

12. Hinds, C. A., Niehaus, A. J., Premanandan, C., Rajala-Schultz, P. J., Rings, D. M. and Lakritz, J. 2014. Characterization of the contributions of Hp-MMP 9 to the serum acute phase protein response of lipopolysaccharide challenged calves. BMC Vet. Res. 10: 261. [Medline] [CrossRef]

13. Horadagoda, A., Eckersall, P. D., Hodgson, J. C., Gibbs, H. A. and Moon, G. M. 1994. Immediate responses in serum TNF $\alpha$ and acute phase protein concentrations to infection with Pasteurella haemolytica A1 in calves. Res. Vet. Sci. 57: 129-132. [Medline] [CrossRef]

14. Horadagoda, N. U., Knox, K. M., Gibbs, H. A., Reid, S. W., Horadagoda, A., Edwards, S. E. and Eckersall, P. D. 1999. Acute phase proteins in cattle: discrimination between acute and chronic inflammation. Vet. Rec. 144: 437-441. [Medline] [CrossRef]

15. Jacobsen, S., Niewold, T. A., Kornalijnslijper, E., Toussaint, M. J. and Gruys, E. 2005. Kinetics of local and systemic isoforms of serum amyloid A in bovine mastitic milk. Vet. Immunol. Immunopathol. 104: 21-31. [Medline] [CrossRef]

16. Kováč, G., Tóthová, C., Nagy, O. and Seidel, H. 2011. Milk amyloid a and selected serum proteins in cows suffering from mastitis. Acta Vet. (Beogr.) 80: 3-9.

17. Kovačević-Filipović, M., Ilić, V., Vujčić, Z., Dojnov, B., Stevanov-Pavlović, M., Mijačević, Z. and Božić, T. 2012. Serum amyloid A isoforms in serum and milk from cows with Staphylococcus aureus subclinical mastitis. Vet. Immunol. Immunopathol. 145: 120-128. [Medline] [CrossRef]

18. Larson, M. A., Weber, A., Weber, A. T. and McDonald, T. L. 2005. Differential expression and secretion of bovine serum amyloid A3 (SAA3) by mammary epithelial cells stimulated with prolactin or lipopolysaccharide. Vet. Immunol. Immunopathol. 107: 255-264. [Medline] [CrossRef]

19. McDonald, T. L., Larson, M. A., Mack, D. R. and Weber, A. 2001. Elevated extrahepatic expression and secretion of mammary-associated serum amyloid A 3 (M-SAA3) into colostrum. Vet. Immunol. Immunopathol. 83: 203-211. [Medline] [CrossRef]

20. Miles, D. G. 2009. Overview of the North American beef cattle industry and the incidence of bovine respiratory disease (BRD). Anim. Health Res. Rev. 10: 101-103. [Medline] [CrossRef]

21. Nielsen, B. H., Jacobsen, S., Andersen, P. H., Niewold, T. A. and Heegaard, P. M. 2004. Acute phase protein concentrations in serum and milk from healthy cows, cows with clinical mastitis and cows with extramammary inflammatory conditions. Vet. Rec. 154: 361-365. [Medline] [CrossRef]

22. Orro, T., Jacobsen, S., LePage, J. P., Niewold, T., Alasuutari, S. and Soveri, T. 2008. Temporal changes in serum concentrations of acute phase 
proteins in newborn dairy calves. Vet. J. 176: 182-187. [Medline] [CrossRef]

23. Petersen, H. H., Nielsen, J. P. and Heegaard, P. M. 2004. Application of acute phase protein measurements in veterinary clinical chemistry. Vet. Res. 35: 163-187. [Medline] [CrossRef]

24. Sack, G. H. Jr. 2018. Serum amyloid A - a review. Mol. Med. 24: 46. [Medline] [CrossRef]

25. Schmidt-Arras, D. and Rose-John, S. 2016. IL-6 pathway in the liver: From physiopathology to therapy. J. Hepatol. 64: 1403-1415. [Medline] [CrossRef]

26. Sun, L. and Ye, R. D. 2016. Serum amyloid A1: Structure, function and gene polymorphism. Gene 583: 48-57. [Medline] [CrossRef]

27. Uhlar, C. M. and Whitehead, A. S. 1999. Serum amyloid A, the major vertebrate acute-phase reactant. Eur. J. Biochem. 265: 501-523. [Medline] [CrossRef]

28. Werling, D., Sutter, F., Arnold, M., Kun, G., Tooten, P. C., Gruys, E., Kreuzer, M. and Langhans, W. 1996. Characterisation of the acute phase response of heifers to a prolonged low dose infusion of lipopolysaccharide. Res. Vet. Sci. 61: 252-257. [Medline] [CrossRef] 